\title{
The Youth Leaders and Their Contributions To The Selected Barangays In The Municipality of Naval, Biliran, Philippines
}

\author{
Grace M. Laude-Concepcion, Noel P. Tancinco \\ College of Education, Naval State University, Naval, Biliran
}

\begin{abstract}
This study assessed the contributions of the youth leaders or Sanguniang Bayan (SK) officials to the development of selective barangays in the municipality of Naval, Biliran, Philippines in terms of: Programs: cleanliness; beautification; cultural activities; information campaign; Projects: sports equipment; indoor games equipment; barangay literacy; day care center; youth/SK Center; infrastructure Activities; Youth Related (SK) Activities: youth sports development; fund raising; talent/ skills recognition. One hundred twenty youth and barangay officials from the eight barangays of the municipality of Naval served as respondents. The descriptive method was used to attain the objectives. The instrument used in this study was a researcher-made survey questionnaire.The results showed that the youth leaders or SanguniangKabataan has moderately implementedprojects, slightly implemented programs and other youth related activities, and moderately implemented the sources of budget allocation to carry out the programs, projects, and activities to the development of the youth. Moreover, it can be drawn that the youth leaders significantly needed the support of the Barangay Chairperson particularly in terms of budget allocation in realization of their programs, projects and other related youth activities.
\end{abstract}

Keywords: Youth Leaders; Contributions; Sangguniang Bayan Officials; Municipality

\section{INTRODUCTION}

The youth is best understood as a period of conversion from the dependence of childhood to adulthood's independence and mindfulness of our interdependence as members of a community. As the young people play an active role in shaping major social, cultural and political diversities and that the system's structure calls for active youth participation.It is the biggest challenge then to the present young Filipino leaders which serve as the principal vehicle of the Filipino youths in fulfilling its sectorial goals. [1]

Eventually, this notion leads to the purpose of creation of the SanguniangKabataan (SK) or Youth Council as a representation of the youth before the government to recognize the importance of the youth in nation building and to serve as a training ground for future leaders in enhancing their involvement in governance. The SanguniangKabataan is a governing body in which Filipinos ages 15 to 17 years old in a barangayhave the right to vote and be voted provided that the youth is register in the KatipunanngKabataan. And this proves that the Philippines provide grass-roots based government-funded political structure for the youth that is recognized nationwide. [2]The youth has seen as active significant piece in the Philippine barangay holding important and worthwhile activities that aims to develop the potentials of the youth and their capabilities. With this, the SanguniangKabataan officials are also seen as icons for their youth constituents in terms of good governance, leadership and moral values.They are exemplify as role models in their community that leads to the zeal of the other people to contribute to the development of the barangay and the municipality as well. [3]

In the other hand, in this recent times based on observations, the SanguniangKabataan had lost its effectiveness in advancing the democratic ideals in service-oriented leadership. The trust and confidence given to this governing body seemed to decline and might be associated to the various issues like inefficiency, abuse or corruption thrown against them. There are studies shown whether to abolish the SanguniangKabataan or not due to the ineffectiveness and malicious acts which contrary to the core value of the SanguniangKabataan.

Hence, it was the purpose of this study to determine the contributions of the SanguniangKabataanto the selected barangays of the municipality of Naval, Biliran to show how effective the governing body to carry its embodied ideals to the society.It will help the researchers and the general public as well to rouse their consciousness whether the SK in their locality is doing their duties and it is appropriate for them to assess them personally based on their performance. Specifically, it sought to answer the following objectives:

1. Determine the profile of the youth leaders (SanguniangKabataan/SK) in Naval, Biliran in terms of: age; gender; civil status; educational attainment;

2. Determine the different contributions of the youth leaders to the development of their respective barangays in terms of: 2.1 Programs: cleanliness; beautification; cultural activities; information campaign; 2.2 Projects: 
sports equipment; indoor games equipment; barangay literacy; day care center; SK Center; Infrastructure Activities; 2.3 Youth Related (SK) Activities: youth sports development; fund raising; talent/ skills recognition;

3. Ascertain the sources of budget allocation to support the programs, projects and activities of the youth leaders (SK);

4. Find out the significant relationship between the contributions of the youth leaders (SK) in terms of programs, projects, and other youth related activities and the sources of budget allocation to support the programs, projects and activities of the youth leaders.

\subsection{Review of Related Literature}

The following literature is reviewed to provide substance and support to the conduct of the study.

The state recognizes the vital role of the youth in nation-building and shall promote and protect their physical, moral, spiritual, intellectual, and social well-being. It shall inculcate in the youth patriotism and nationalism, and courage their involvement in public and civic affairs. In response to this constitutional provision the congress created the SK-Youth Council or SanguniangKabataan (SK) for the purpose of introducing the young people to government in local, provincial and national levels. [4]

There shall be in every barangay a SangguniangKabataan to be composed of a chairman, seven members, asecretary and a treasurer.They are elected by the members of,theKatipunanngKabataanin elections conducted by the Commission on Elections (COMELEC). The powers andfunctions of the SangguniangKabataan are as follows:

1. To promulgate resolutions necessary to carry out the objectives of the youth inthe barangay, in accordance with applicable provisions of the Code;

2. Initiate programs designed to enhance the social, political, economic, cultural,and intellectual, moral, spiritual and physical development of the members;

3. Hold fund raising activities, the proceeds of which shall be tax exempt and shallaccrue to the SangguniangKabataan general fund;

4. Create such bodies or committees necessary to effectively carry out itsprograms and activities;

5. Submit annual end-of-term reports to the Sangguniang Barangay on theirprojects and activities;

6. Consult and coordinate with all youth organizations in the barangay for policyformulation and program implementation;

7. Coordinate with the Presidential Council for Youths (PCYA) and otherNational Government Agencies (NGA) concerned for the implementation ofyouth development projects and programs at the national level;

8. Exercise such other powers and perform such other duties and functions as theSangguniang Barangay may determine or delegate or as may be prescribed bylaw or ordinance. [5]

In addition to, the SanguniangKabataan has the rights, privileges, duties and obligations like: the right to participate in all activities; the right to avail oneself of the service of the Federation; the right to vote, and if qualified for a position, to be voted upon, the right to use the facilities of the Federation.In every barangay, a Barangay Youth Council is organized as the governing body of the Youth Assembly. Its primary objective is to enhance the development of the youth in the country. The Council promulgates resolutions necessary to carry out the objectives of the youth. Most activities initiated by the council in the country are tree planting, clean-up drives for rivers and lakes, waste segregation, etc.The SK officials are expected to fulfill their duties and responsibilities provided in the Local Government Code. However, Most of the bills passed in the Philippine Congress, recognize the dismal performance of SK through the years, citing unresponsive, uncreative and very limited SK programs and projects such aspaliga, beauty pageants, clean and green, waiting sheds, and signage or worse none at all. These findings led to the conclusion that the potentials of the SK are not beingmaximized, resulting in short-term projects and programs largely limited to sports andinfrastructure development, and environmental protection. [4]

The SangguniangKabataan has tremendous potential to become a true venue for youth participation in governance. Giving the youth a seat in local governments, providing them with a budget mandated by law, listening to them and providing venues for them to meaningfully take part in shaping local policies andprograms like sports, infrastructure development and environmental protection couldtransform young people into significant members of the community. [4]

Abolishing the SangguniangKabataan is an impractical way and it will resulted to a negative effect on the youth participation in the local governance because the SK is an important mechanism to uphold the interest and welfare of the youth sector through a democratically established institution for governance. And abolishing the SK is like an equivalent to repression of the democratic rights and welfare of the youth. [5]

\subsection{Framework of the Study}

This study utilized the conceptual framework as its main foundation in the due course of its proceedings.

Conceptual Framework. The ultimate aim of this study is on the youth leaders and their contributions to the selected barangays in the municipality of Naval, Biliran. This study quantifies the parameters in terms of the profile of the youth leaders (SK) as to: age, gender, civil and educational attainment. It also leaned into the contributions of the youth leaders in terms of programs, projects, and other youth related activities and the 
sources of its budget allocation. In addition, the variables were also tested to determine the significant relationship.Figure 1 presents the conceptual framework of the study.

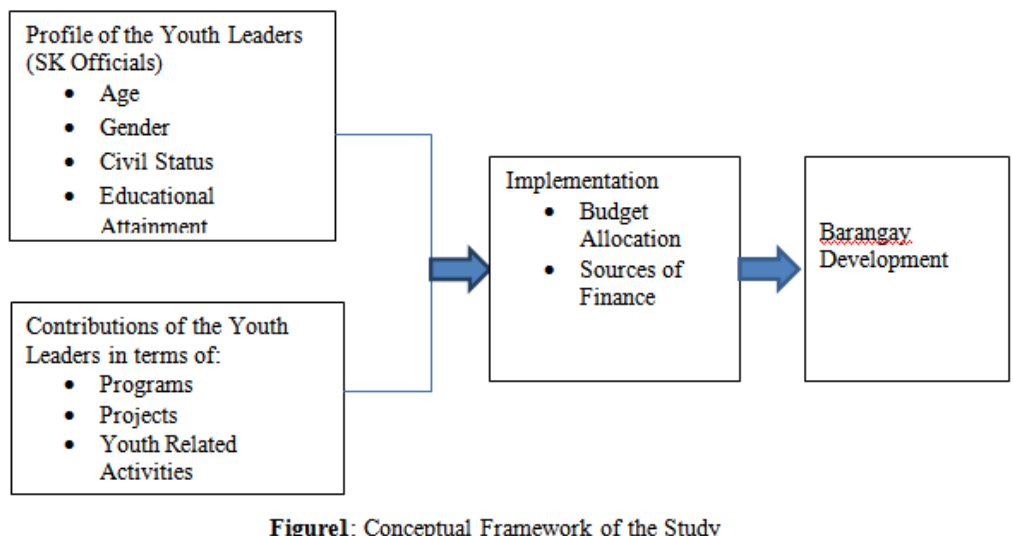

\subsection{Scope and Delimitation of the Study}

This study covered the contributions of the youth leaders (SK Officials) and was only limited to selected Barangays of Naval, Biliran namely: Atipolo, Calumpang, Caray-Caray, Larazzabal, Padre Inocentes Garcia, Sabang, Sto. Niño, and Sto. Smo. Rosario. It also focused on the sources of budget allocation to support the programs, projects and activities of the youth leaders.

\section{METHODOLOGY}

This study employed the descriptive survey method of research. Data are gathered and descriptive statistics are then used to analyze such data.The respondents of the study were the 8 Barangay Chairpersons, 8 Barangay Secretaries, 8 Barangay Treasurers, 32 Barangay Councilors, 8 SK Chairpersons, and 56 SK Councilors of the eight barangays of Naval, Biliran.This study employed the survey questionnaire. The datagathering instrument is consist of two parts. Part I deals with the demographic profile of the respondents in terms of age, gender, civil status and educational attainment. Part II deals on the contributions of the youth leaders in terms of programs, projects, and other related youth activities. And Part III deals with the sources of budget allocation to support the programs, projects and activities of the youth leaders.

The data gathered during the survey was coded, analyzed and presented in tabular form using descriptive statistics such as frequencies, mean, range, relative frequency, percent, and weighted mean. The Likert Scale was used in the questionnaire, with a rating scale of 1 to 5 where five was the highest and one was the lowest.

\section{RESULTS AND DISCUSSION}

3.1 Profile of the respondents Specifically, the components of the respondents profile were age, gender, civil status and educational attainment.

Table 1:Profile of the Respondents

\begin{tabular}{|l|c|c|}
\hline Variables & f & \% \\
\hline Age & 80 & 66.67 \\
$20-24$ & 5 & 4.17 \\
$25-29$ & 24 & 20.0 \\
$30-34$ & 9 & 7.5 \\
$35-39$ & 2 & 1.67 \\
$40-$-above & $\mathbf{1 2 0}$ & $\mathbf{1 0 0 . 0}$ \\
Total & & \\
\hline Gender & 64 & 53.3 \\
Male & 56 & 46.6 \\
Female & $\mathbf{1 2 0}$ & $\mathbf{1 0 0 . 0}$ \\
Total & & 60.0 \\
\hline Civil Status & 72 & 36.0 \\
Single & 44 & 1.6 \\
Married & 2 & 1.6 \\
Separated & 2 & \\
Widow(er) & & \\
& & \\
\hline
\end{tabular}




\begin{tabular}{|l|c|c|} 
Total & $\mathbf{1 2 0}$ & $\mathbf{1 0 0 \%}$ \\
\hline $\begin{array}{l}\text { Educational } \\
\text { Attainment }\end{array}$ & & \\
& & \\
Elementary & 15 & 4.16 \\
Graduate & & \\
High School Level & 16 & 13.33 \\
High School & 23 & 19.16 \\
Graduate & & \\
College Level & 55 & 45.83 \\
College Graduate & 21 & 17.5 \\
Total & $\mathbf{1 2 0}$ & $\mathbf{1 0 0 \%}$ \\
\hline
\end{tabular}

As regards to age, among the 120 respondents, 66.67percent belongs to the age group of 20-24 years old, while the age groups 40 and abovegot the lowest percentage. This means that the respondents are young adult and mature enough to be committed on their responsibilities. Gender, the data revealed that 64 percent were male, while the female was only 56 percent. This shows that the male dominates in the leadership positions. Civil status, among the respondents, 72 percent were single, 44 percent were married, and 2 percent were separated and widow(er). This suggest that the respondents have much focus on their responsibilities as leaders since they don't have family related activities to attend to. For educational attainment, 55 percent were college graduates and 15 percent elementary graduates. This implies that majority of the respondents were educated and knowledgeable on their leadership positions in their respective barangays.

\subsection{Contributions of the Youth Leaders}

The succeeding table presents the contributions of the youth leaders in the selected municipalities of Naval, Biliran. It used the 5-point scale categorized into: (5) absolutely implemenedt; (4) very implemented; (3) implemented; (2) moderately implemented; and (1) not implemented. The weighted means were computed, analyzed, and presented in table 2 with their corresponding interpretations.

\subsubsection{Programs of SanguniangKabataan Officials}

Table 2: Programs of SanguniangKabataan Officials

\begin{tabular}{|c|c|c|c|c|c|c|c|}
\hline \multirow{2}{*}{ Cleanliness } & $\mathbf{A I}$ & VI & I & MI & NI & \multirow{2}{*}{ WM } & \multirow{2}{*}{ DESCRIPTION } \\
\hline & 5 & 4 & 3 & 2 & $\mathbf{1}$ & & \\
\hline $\begin{array}{l}\text { 1. Cleaning } \\
\text { the streets and } \\
\text { surroundings }\end{array}$ & 155 & 56 & 45 & 24 & 48 & 2.73 & $\begin{array}{l}\text { Much } \\
\text { Implemented }\end{array}$ \\
\hline $\begin{array}{l}\text { 2. Providing } \\
\text { waste box in } \\
\text { the streets }\end{array}$ & 110 & 60 & 57 & 36 & 46 & 2.55 & $\begin{array}{l}\text { Moderately } \\
\text { Implemented }\end{array}$ \\
\hline $\begin{array}{l}\text { 3. Cutting the } \\
\text { grasses along } \\
\text { the road }\end{array}$ & 130 & 28 & 60 & 34 & 50 & 2.52 & Moderately \\
\hline $\begin{array}{l}\text { 4. Cleaning } \\
\text { the drainage }\end{array}$ & 90 & 44 & 45 & 20 & 63 & 2.18 & $\begin{array}{l}\text { Moderately } \\
\text { Implemented }\end{array}$ \\
\hline $\begin{array}{l}\text { 5. Cleaning } \\
\text { along the sea } \\
\text { shore }\end{array}$ & 90 & 44 & 45 & 20 & 63 & 2.18 & $\begin{array}{l}\text { Slightly } \\
\text { Implemented }\end{array}$ \\
\hline \multicolumn{6}{|l|}{ TWM } & 2.51 & $\begin{array}{l}\text { Moderately } \\
\text { Implemented }\end{array}$ \\
\hline \multirow{2}{*}{ Beautification } & AI & VI & I & MI & NI & \multirow{2}{*}{ WM } & \multirow{2}{*}{ DESCRIPTION } \\
\hline & 5 & 4 & 3 & 2 & 1 & & \\
\hline $\begin{array}{l}\text { 1. Planting } \\
\text { flowering } \\
\text { plants }\end{array}$ & 120 & 36 & 48 & 38 & 52 & 2.45 & $\begin{array}{l}\text { Slightly } \\
\text { Implemented }\end{array}$ \\
\hline $\begin{array}{l}\text { 2. Painting the } \\
\text { stones }\end{array}$ & 90 & 36 & 33 & 28 & 68 & 2.13 & $\begin{array}{l}\text { Slightly } \\
\text { Implemented }\end{array}$ \\
\hline $\begin{array}{l}\text { 3. Painting the } \\
\text { fence }\end{array}$ & 110 & 32 & 33 & 28 & 68 & 2.13 & $\begin{array}{l}\text { Slightly } \\
\text { Implemented }\end{array}$ \\
\hline
\end{tabular}




\begin{tabular}{|l|l|l|l|l|l|l|l|}
\hline Landscaping & & & & & & & Implemented \\
\hline $\begin{array}{l}\text { 5. Tree } \\
\text { Planting }\end{array}$ & 120 & 44 & 18 & 22 & 68 & 2.27 & $\begin{array}{l}\text { Slightly } \\
\text { Implemented }\end{array}$ \\
\hline TWM & & & & & & & $\begin{array}{l}\text { Slightly } \\
\text { Implemented }\end{array}$ \\
\hline
\end{tabular}

\begin{tabular}{|c|c|c|c|c|c|c|c|}
\hline \multirow{2}{*}{ Cultural } & AI & VI & I & MI & NI & \multirow{2}{*}{ WM } & \multirow{2}{*}{ DESCRIPTION } \\
\hline & 5 & 4 & 3 & 2 & 1 & & \\
\hline 1. Hudyaka & 65 & 44 & 48 & 28 & 66 & 2.09 & $\begin{array}{l}\text { Slightly } \\
\text { Implemented }\end{array}$ \\
\hline $\begin{array}{l}\text { 2. Cultural } \\
\text { Competition }\end{array}$ & 55 & 36 & 45 & 36 & 67 & 1.99 & $\begin{array}{l}\text { Slightly } \\
\text { Implemented }\end{array}$ \\
\hline $\begin{array}{l}\text { 3. Cultural } \\
\text { Show }\end{array}$ & 45 & 36 & 60 & 32 & 66 & 1.99 & $\begin{array}{l}\text { Slightly } \\
\text { Implemented }\end{array}$ \\
\hline $\begin{array}{l}\text { 4. Beauty } \\
\text { Competition }\end{array}$ & 60 & 40 & 48 & 44 & 60 & 2.1 & $\begin{array}{l}\text { Slightly } \\
\text { Implemented }\end{array}$ \\
\hline TWM & & & & & & 2.04 & $\begin{array}{l}\text { Slightly } \\
\text { Implemented }\end{array}$ \\
\hline
\end{tabular}

\begin{tabular}{|c|c|c|c|c|c|c|c|}
\hline Information Drive & AI & VI & I & MII & NI & \multirow{2}{*}{ WM } & \multirow{2}{*}{ DESCRIPTION } \\
\hline Information Drive & 5 & 4 & 3 & 2 & 1 & & \\
\hline 1. Literacy Training & 80 & 40 & 27 & 36 & 67 & 2.08 & $\begin{array}{l}\text { Slightly } \\
\text { Implemented }\end{array}$ \\
\hline $\begin{array}{l}\text { 2. Youth } \\
\text { forums/Symposium }\end{array}$ & 60 & 56 & 36 & 38 & 62 & 2.1 & $\begin{array}{l}\text { Slightly } \\
\text { Implemented }\end{array}$ \\
\hline $\begin{array}{l}\text { 3. Leadership } \\
\text { training }\end{array}$ & 70 & 44 & 39 & 54 & 55 & 2.18 & $\begin{array}{l}\text { Slightly } \\
\text { Implemented }\end{array}$ \\
\hline $\begin{array}{l}\text { 4. Values and moral } \\
\text { inculcation }\end{array}$ & 70 & 48 & 51 & 36 & 61 & 2.22 & $\begin{array}{l}\text { Slightly } \\
\text { Implemented }\end{array}$ \\
\hline $\begin{array}{l}\text { 5. Anti-drug abuse } \\
\text { campaign }\end{array}$ & 90 & 64 & 66 & 30 & 49 & 2.49 & $\begin{array}{l}\text { Slightly } \\
\text { Implemented }\end{array}$ \\
\hline $\begin{array}{l}\text { 6. Waste } \\
\text { management }\end{array}$ & 100 & 60 & 39 & 34 & 55 & 2.4 & $\begin{array}{l}\text { Slightly } \\
\text { Implemented }\end{array}$ \\
\hline TWM & & & & & & 2.25 & \begin{tabular}{|l|} 
Slightly \\
Implemented
\end{tabular} \\
\hline
\end{tabular}

Table 2 presents the programs of youth leaders (SK officials). Cleanliness got the highest mean of 2.51 described as moderately implemented while beautification, cultural, and information drive having 2.25, 2.04 and 2.25 mean respectively were described as slightly implemented. The finding implies that with the overall mean of 2.26 the programs were only slightly implemented by the youth leaders (SK officials). This also suggests that it could be the barangays already maintained cleanliness and beautification and that the youth leaders did not find much difficulty on implementing it.

\subsubsection{Projects of Youth Leaders}

Table 3: Projects of Youth Leaders

\begin{tabular}{|l|l|l|l|l|l|l|l|}
\hline \multicolumn{1}{|c|}{$\begin{array}{c}\text { Sports } \\
\text { Equipment }\end{array}$} & AI & VI & I & MI & NI & \multirow{2}{*}{ WM } & DESCRIPTION \\
\cline { 2 - 7 } $\begin{array}{l}1 . \\
\text { Volleyball }\end{array}$ & 145 & 40 & 24 & 40 & 53 & 2.52 & $\begin{array}{l}\text { Moderately } \\
\text { Implemented }\end{array}$ \\
\hline $\begin{array}{l}2 . \\
\text { Basketball }\end{array}$ & 305 & 48 & 30 & 14 & 30 & 3.56 & Much Implemented \\
\hline 3. Net & 180 & 76 & 54 & 14 & 40 & 3.03 & $\begin{array}{l}\text { Moderately } \\
\text { Implemented }\end{array}$ \\
\hline $\begin{array}{l}\text { 4. Post for } \\
\text { Net }\end{array}$ & 135 & 108 & 45 & 10 & 46 & 2.87 & $\begin{array}{l}\text { Moderately } \\
\text { Implemented }\end{array}$ \\
\hline TWM & & & & & & & $\begin{array}{l}\text { Moderately } \\
\text { Implemented }\end{array}$ \\
\hline $\begin{array}{l}\text { Indoor } \\
\text { Games }\end{array}$ & AI & VI & I & MI & NI & \multirow{2}{*}{ WM } & DESCRIPTION \\
\cline { 2 - 7 } & 5 & 4 & 3 & 2 & 1 & \\
\hline
\end{tabular}




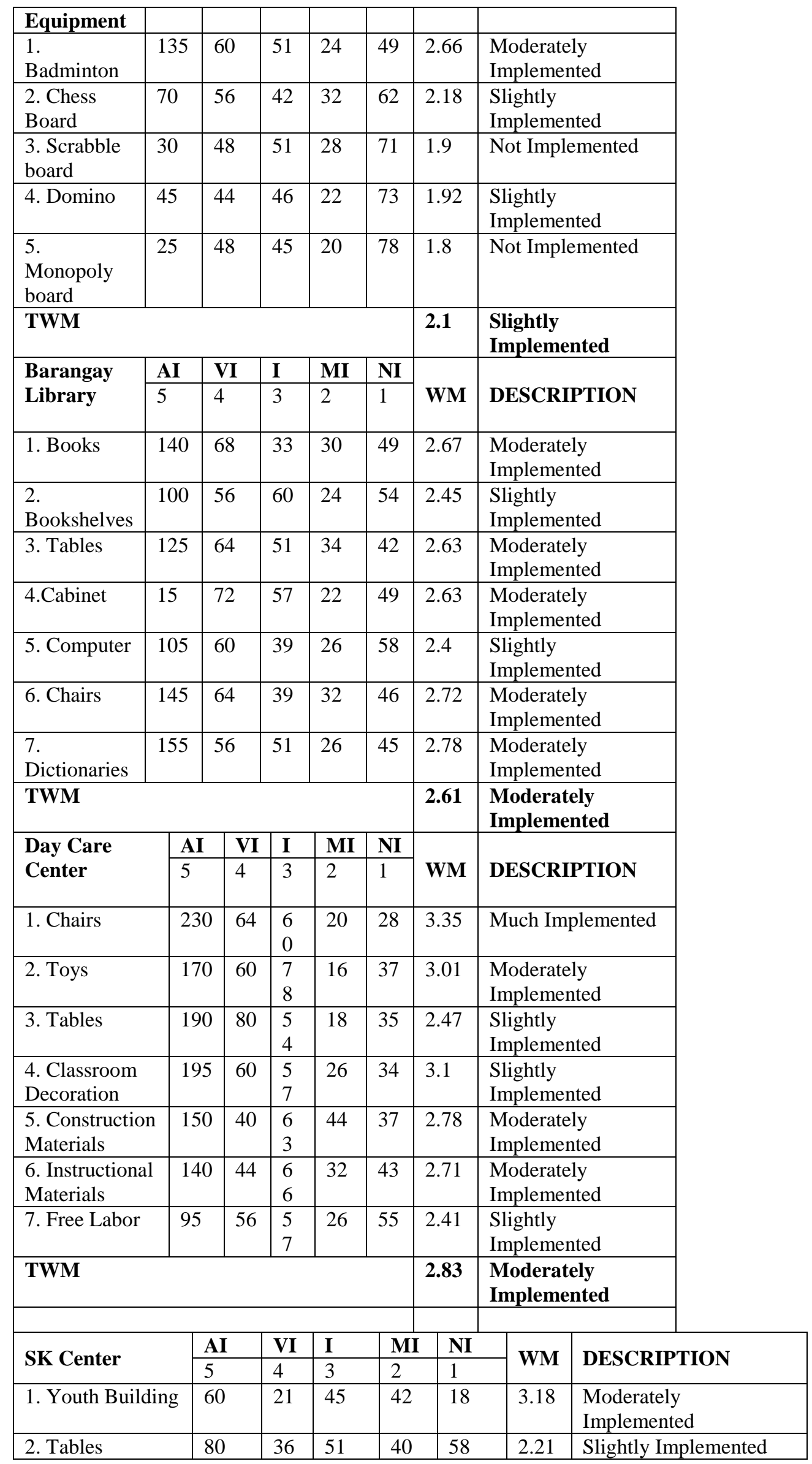




\begin{tabular}{|c|c|c|c|c|c|c|c|}
\hline 3. Chairs & 75 & 48 & 54 & 26 & 62 & 2.21 & Slightly \\
\hline 4.Television & 50 & 32 & 48 & 30 & 71 & 1.93 & Slightly Implemented \\
\hline 5. Computer & 110 & 52 & 45 & 30 & 55 & 2.43 & Slightly Implemented \\
\hline 6. Electric Fan & 110 & 60 & 36 & 28 & 57 & 2.43 & Slightly Implemented \\
\hline \multicolumn{6}{|l|}{ TWM } & 2.4 & Slightly Implemented \\
\hline \multirow{2}{*}{$\begin{array}{l}\text { Infrastructure } \\
\text { Projects }\end{array}$} & AI & VI & I & MI & NI & \multirow[b]{2}{*}{ WM } & \multirow[b]{2}{*}{ DESCRIPTION } \\
\hline & 5 & 4 & 3 & 2 & 1 & & \\
\hline 1. Waiting Shed & 140 & 60 & 24 & 42 & 48 & 2.62 & $\begin{array}{l}\text { Moderately } \\
\text { Implemented }\end{array}$ \\
\hline $\begin{array}{l}\text { 2. Stage } \\
\text { Construction }\end{array}$ & 120 & 52 & 33 & 32 & 56 & 2.44 & Slightly Implemented \\
\hline $\begin{array}{l}\text { 3. Basketball } \\
\text { Court }\end{array}$ & 200 & 56 & 39 & 24 & 41 & 3 & $\begin{array}{l}\text { Moderately } \\
\text { Implemented }\end{array}$ \\
\hline \multicolumn{6}{|l|}{ TWM } & 2.69 & $\begin{array}{l}\text { Moderately } \\
\text { Implemented }\end{array}$ \\
\hline
\end{tabular}

From Table 3, it could be observed thatsports equipment, barangay library, day care center, and infrastructure activities have a mean 3.0, 2.61, 2.83, and 2.69 respectively described as moderately implemented. Parlor games equipment and Youth (SK) Center has a mean of 2.1 and 2.24 respectively described as slightly implemented. The overall mean of 2.58 implies that the projects of SanguniangKabataan Officials were moderately implemented. The result implies that the projects of the youth leaders or SK Officials were tangibly needed in the barangays to cater the needs particularly the young.

\subsubsection{Youth Related Activities}

Table 4: Youth Related Activities

\begin{tabular}{|l|l|l|l|l|l|l|l|}
\hline $\begin{array}{l}\text { Youth Related } \\
\text { Activities }\end{array}$ & AI & VI & I & MI & NI & \multirow{2}{*}{ WM } & DESCRIPTION \\
\cline { 2 - 7 } & 5 & 4 & 3 & 2 & 1 & 2.17 & $\begin{array}{l}\text { Slightly } \\
\text { Implemented }\end{array}$ \\
\hline 1. Sports Clinic & 65 & 36 & 69 & 30 & 60 & 1.97 & $\begin{array}{l}\text { Slightly } \\
\text { Implemented }\end{array}$ \\
\hline $\begin{array}{l}\text { 2. Workshop/ } \\
\text { Seminars }\end{array}$ & 50 & 28 & 48 & 46 & 64 & 2.17 & $\begin{array}{l}\text { Slightly } \\
\text { Implemented }\end{array}$ \\
\hline $\begin{array}{l}\text { 3. Referee } \\
\text { Training }\end{array}$ & 70 & 28 & 54 & 54 & 54 & 24.24 & $\begin{array}{l}\text { Slightly } \\
\text { Implemented }\end{array}$ \\
\hline $\begin{array}{l}\text { 4. Sports } \\
\text { Tournament }\end{array}$ & 140 & 48 & 57 & 24 & 0 & $\mathbf{2 . 1 4}$ & $\begin{array}{l}\text { Slightly } \\
\text { Implemented }\end{array}$ \\
\hline \begin{tabular}{l} 
TWM \\
\hline
\end{tabular} & & & & & &
\end{tabular}

\begin{tabular}{|l|l|l|l|l|l|l|l|}
\hline \multirow{2}{*}{ Fund Raising } & AI & VI & I & MI & NI & WM & DESCRIPTION \\
\cline { 2 - 7 } & 5 & 4 & 3 & 2 & 1 & 2.45 & $\begin{array}{l}\text { Slightly } \\
\text { Implemented }\end{array}$ \\
\hline 1. Benefit Dance & 105 & 40 & 66 & 51 & 51 & 2.35 & $\begin{array}{l}\text { Slightly } \\
\text { Implemented }\end{array}$ \\
\hline 2. Cockfight & 85 & 36 & 69 & 42 & 50 & 1.98 & $\begin{array}{l}\text { Slightly } \\
\text { Implemented }\end{array}$ \\
\hline 3. Raffle Draw & 65 & 28 & 51 & 20 & 73 & 1.92 & $\begin{array}{l}\text { Slightly } \\
\text { Implemented }\end{array}$ \\
\hline $\begin{array}{l}\text { 4. Mini-Concert } \\
\text { in Barangay }\end{array}$ & 50 & 36 & 24 & 52 & 68 & 1.58 & Slightly \\
\hline 5. Bingo Games & 15 & 28 & 30 & 34 & 83 & $\mathbf{2 . 0 6}$ & $\begin{array}{l}\text { Slightly } \\
\text { Implemented }\end{array}$ \\
\hline \begin{tabular}{l} 
TWM \\
\hline
\end{tabular}
\end{tabular}

Talent/Skill Recognition

\begin{tabular}{|l|l|l|l|l|} 
AI & VI & I & MI & NI \\
\hline 5 & 4 & 3 & 2 & 1 \\
\hline
\end{tabular}




\begin{tabular}{|l|l|l|l|l|l|l|l|}
\hline $\begin{array}{l}\text { 1. Modern } \\
\text { Dance }\end{array}$ & 85 & 32 & 51 & 34 & 60 & 2.18 & $\begin{array}{l}\text { Slightly } \\
\text { Implemented }\end{array}$ \\
\hline 2. Pop Idol & 55 & 60 & 69 & 34 & 54 & 2.27 & $\begin{array}{l}\text { Slightly } \\
\text { Implemented }\end{array}$ \\
\hline 3. Talent Show & 65 & 60 & 60 & 38 & 53 & 2.3 & $\begin{array}{l}\text { Slightly } \\
\text { Implemented }\end{array}$ \\
\hline $\begin{array}{l}\text { 4. Singing } \\
\text { Competition }\end{array}$ & 90 & 68 & 51 & 32 & 52 & 2.44 & $\begin{array}{l}\text { Slightly } \\
\text { Implemented }\end{array}$ \\
\hline TWM & & & & $\mathbf{2 . 3}$ & $\begin{array}{l}\text { Slightly } \\
\text { Implemented }\end{array}$ \\
\hline
\end{tabular}

Table 4 showed the summary of activities of the youth leaders or SanguniangKabataan officials in terms of

youth sports development, fund raising, and talent/skill recognition. These activities were all found to be slightly implemented by the SK officials in the barangays with the overall mean of 2.17 . This may suggest that the youth might be occupied with other relevant activities in which they have to prioritize like on their studies or family obligations, and one way or another it might be true also to the part of the youth leaders. However, from Malaluan study it was stated that the trainings provided are not at all efficient and the SK officials themselves are mostly not serious with the objectives of the seminars. Some have their personal motives on attending other than learning things to enhance their performance in the barangay.

\subsection{Sources of Budget Allocation}

Table 5: Sources of Budget Allocation

\begin{tabular}{|l|l|l|}
\hline Sources of Budget Allocation & Mean & Description \\
\hline Request Resolution to Barangay Council & 3.54 & Implemented \\
\hline $\begin{array}{l}\text { Majority Request from the Barangay } \\
\text { Constituents }\end{array}$ & 3.15 & Moderately Implemented \\
\hline Request Resolution for Funding & 3.09 & Moderately Implemented \\
\hline $\begin{array}{l}\text { Request from the Barangay Development } \\
\text { Council to Avail SK Fund }\end{array}$ & 3.21 & Moderately Implemented \\
\hline Submitted Program Work & 2.12 & Slightly Implemented \\
\hline Total & $\mathbf{3 . 0 2}$ & Moderately Implemented \\
\hline
\end{tabular}

Table 5 presents the sources of budget allocation, looking at it the request resolution to Barangay Council got

the highest mean of 3.54 described as implemented and the submitted program work is slightly implemented. This clearly implies that the main source of budget allocation of the youth leaders or SK officials came from requests resolution to barangay council to implement various projects or activities. This may further suggest that it depends upon on the Barangay Council to decide as to what programs or activities that the SanguniangKabataan plans will be implemented.

\subsection{Youth Leaders Contributions and Sources of of budget allocation}

The relationship between the youth leaders' contributions and sources of of budget allocation is presented in table 6.

Table 6: Relationship of youth leaders' contributions and sources of of budget allocation

\begin{tabular}{|l|l|l|l|l|}
\hline Variables & r. & Computed-t & table value & Interpretation \\
\hline $\begin{array}{l}\text { Youth Leaders } \\
\text { Contributions and } \\
\begin{array}{l}\text { Sources of Budget } \\
\text { Allocation }\end{array}\end{array}$ & .70 & 16.128 & & \\
\hline
\end{tabular}

alpha level of significance $(\infty)=\mathbf{0 . 0 5}$

The null hypothesis was rejected since the computed value was 16.128 is greater than the table value 15.507. This means that the youth leaders' contributions affect the sources of budget allocation to support the programs, projects and activities of the youth leaders. Findings suggest that contributions of the youth leaders affect the sources of budget allocation to support the programs, projects and activities of the SanguniangKabataan. This further implies that the effectiveness of the youth leaders (SK Officials) to carry out their responsibilities depends upon on the contributions the youth leaders can implement, and its implementation depends also on the budget allocated for the particular programs, projects or activity. 


\section{CONCLUSION}

Most of the respondents were young adult aging 20-24 years old. The male respondents outnumbered the female respondents and most of them are single. There were more projects of youth leaders (SK Officials) were implemented than the programs and related youth activities. There is a significant relationship of youth contributions (SK Officials) in relation to programs, projects, and youth related activities to the sources of budget allocation that will contribute to the development of the barangays. Hence, the barangay chairperson's cooperation was really needed by the youth leaders (SK Officials).

\section{RECOMMENDATIONS}

The youth leaders (SK Officials) must possess enough knowledge on leadership, consistent decision making and positive outlook in life. The youth leaders should provide various activities in order to deviate the interest of their fellow youth from delinquent acts. Collaboration of work between barangay officials and youth leaders (SK Officials) should take place so that they could implement more contributions to their barangay constituents. The youth leaders should be more motivated to serve for the welfare of all individuals not only to their community but also to other places rather than clinging to their personal interests.

\section{REFERENCES}

[1] United Nations Educational Scientific and Cultural Organizations (UNESCO). General Assembly. Retrieved November 18, 2011

[2] from http://www.youthpolicy.org/basics/2001_WPAY_Implementation_Report.pdf

[3] KatipunanngKabataan and SanguniangKabataan Constitution and By-Laws. Retrieved December 5, 2011.

fromhttpregion5.dilg.gov.ph/attachments/article/182/Related_Laws_Sk_Constitution_and_By_Laws.pdf

[4] Malaluan, Alyssa Clarizze E., et al. Performance of SangguniangKabataan Officials As Mandated By the Local Government Code of 1991. (2014).

[5] 1987 Philippines Constitution.

[6] KatipunanngKabataan and SanguniangKabataan Constitution and By-Laws. RetrievedDecember 5, 2011. fromhttp://region5.dilg.govph/attachments/article/182/Related_Laws_Sk_Constitution_and_By_Laws.pdf

[7] Sections 423-439, Chapter 8, Title I, Book III, LocalGovernment Code

[8] Santos, Aloi. Study on the Abolition of SanguniangKabataanTowards an Empowered Youth Representation. 2015

[9] Santos, Aloi. Study on the Abolition of SanguniangKabataanTowards an Empowered Youth Representation. 2015

[10] The SanguniangKabataanExperience

[11] The UN Convention on the Rights of the Child | UNICEF UK.Retrieved fromwww.unicef.org.uk

[12] Robertson, Fiona Mary. The Study of Youth Political Participation in Poland and Romania.(2009)

[13] Moguel, Kelly. The Experience of Influence Among Youth Leaders. (2015) 